\title{
Products and technologies for treating patients with evidence-based pressure ulcers
}

\author{
Produtos e tecnologias para o tratamento de pacientes com lesões por pressão baseadas em evidências \\ Productos y tecnologías para el tratamiento de pacientes con lesiones por presión basadas en evidencias
}

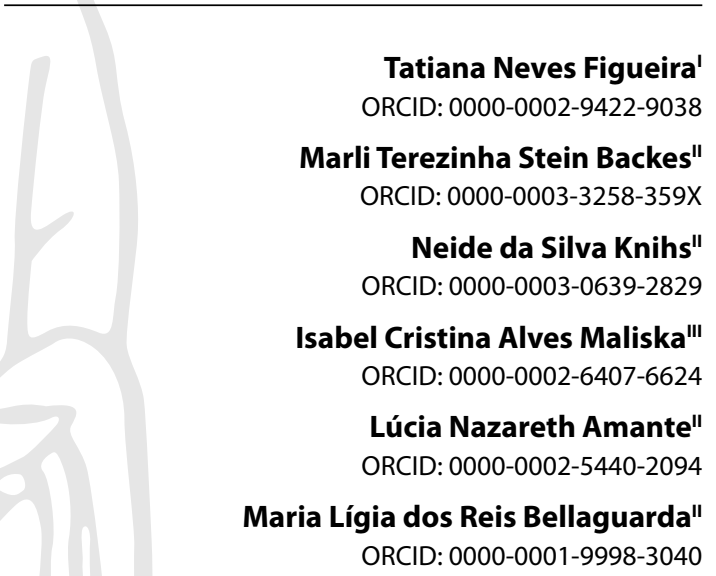

'Secretaria de Estado da Saúde de Santa Catarina. Florianópolis, Santa Catarina, Brazil. "Universidade Federal de Santa Catarina. Florianópolis, Santa Catarina, Brazil.

II' Universidade Federal de Santa Catarina, Hospital Universitário Professor Polydoro Ernane de São Thiago.

Florianópolis, Santa Catarina, Brazil.

How to cite this article:

Figueira TN, Backes MTS, Knihs NS, Maliska ICA, Amante LN Bellaguarda MLR. Products and technologies for treating patients with evidence-based pressure ulcers.

Rev Bras Enferm. 2021;74(5):e20180686. https://doi.org/10.1590/0034-7167-2018-0686

Corresponding author: Marli Terezinha Stein Backes E-mail:marli.backes@ufsc.br

EDITOR IN CHIEF: Dulce Barbosa ASSOCIATE EDITOR: Antonio José de Almeida Filho

Submission: $08-27-2018$

Approval: 02-26-202

\section{ABSTRACT}

Objective: to identify products/technologies for treating patients with pressure ulcers with an evidence level 1. Method: this is an integrative literature review. A survey of studies was carried out using the United States National Library of Medicine Portal, Scientific Electronic Library Online, Virtual Health Library, National Library of Medicine;, The Cumulative Index to Nursing and Allied Health Literature, Latin American and Caribbean in Health Sciences, Nursing Database. Results: sixteen articles were selected with level of evidence 1. The findings were categorized into five categories: Topical therapy to promote healing; Alternative therapy to promote healing; Topical therapy to promote debridement; Topical therapy to minimize lesion contamination; Topical therapy to reduce lesion size. Final considerations: the 17 products/ technologies identified favor/fast healing, debridement, minimize contamination and reduce lesion size to accelerate healing.

Descriptors: Evaluation; Nursing Care; Occlusive Dressings; Therapeutics; Pressure Ulcer.

\section{RESUMO}

Objetivo: identificar produtos/tecnologias para tratamento de pacientes com lesões por pressão com nível de evidência 1. Método: revisão integrativa da literatura. Realizou-se levantamento de estudos, utilizando bibliotecas virtuais: Portal da Biblioteca Nacional de Medicina dos Estados Unidos, Scientific Eletronic Library Online, Biblioteca Virtual em Saúde, e bases de dados: National Library of Medicine. The Cumulative Index to Nursing and Allied Health Literature, Literatura Latino-Americana e do Caribe em Ciências da Saúde, Base de Dados de Enfermagem. Resultados: selecionaram-se 16 artigos com nível de evidência 1. Os achados foram categorizados em cinco categorias: Terapia tópica para promoção da cicatrização; Terapia alternativa para promover a cicatrização; Terapia tópica para promover o desbridamento; Terapia tópica para minimizar a contaminação da lesão; Terapia tópica para redução do tamanho das lesões. Considerações finais: os 17 produtos/tecnologias identificados favorecem/agilizam a cicatrização, o desbridamento, minimizam a contaminação e reduzem o tamanho das lesões para acelerar a cicatrização.

Descritores: Avaliação; Cuidados de Enfermagem; Curativos Oclusivos; Terapêutica; Úlcera por Pressão.

\section{RESUMEN}

Objetivo: identificar productos/tecnologías para el tratamiento de pacientes con úlceras por presión con nivel de evidencia 1. Método: revisión integradora de la literatura. Los estudios se realizaron utilizando bibliotecas virtuales: Portal de la Biblioteca Nacional de Medicina de los Estados Unidos, Biblioteca Electrónica Científica en Línea, Biblioteca Virtual en Salud y bases de datos: Biblioteca Nacional de Medicina ${ }^{\circ}$, The Cumulative Index to Nursing and Allied Health Literature, Latinoamericano y Literatura del Caribe en Ciencias de la Salud, Base de datos de enfermería. Resultados: se seleccionaron 16 artículos con nivel de evidencia 1. Los hallazgos se categorizaron en cinco categorías: Terapia tópica para promover la curación Terapia alternativa para promover la curación; Terapia tópica para promover el desbridamiento; Terapia tópica para minimizar la contaminación de la úlcera; Terapia tópica para reducir el tamaño de las úlceras. Consideraciones finales: los 17 productos/tecnologías identificados favorecen/aceleran la curación, el desbridamiento, minimizan la contaminación y reducen el tamaño de las lesiones para acelerar la curación.

Descriptores: Evaluación; Cuidados de Enfermería; Apósitos Oclusivos; Terapia; Úlceras por Presión. 


\section{INTRODUCTION}

The technological evolution of the last years has provided advances, improvement and improvements in the health scenario. Among the technologies that have evolved the most are those related to injury/wound treatment through new products and technologies that are constantly presented to the health team, in particular, to nurses who develop direct patient care.

Assistance to patients with pressure ulcers (PU) must be performed by the multidisciplinary team, but it is up to nurses to manage this care, as they have responsibility and legal support from the respective Federal Nursing Council (COFEN - Conselho Federal de Enfermagem). Therefore, nurses are in constant search of strategies both for prevention and assessment, as well as for the treatment of these injuries, in order to promote, together with the nursing and health team, favorable conditions to avoid them, as well as to treat them, when necessary.

One of the challenges experienced by nurses in the care of injuries is related to PU that result from pressure on a certain area of the body. This type of lesions can arise from the combination of mechanical, biochemical and physiological factors, intrinsic (internal) and/or extrinsic (external), so that when pressure applied on a given area is prolonged, a chain of cellular and vascular events occurs that can lead to tissue necrosis ${ }^{(1-2)}$. The development of PUs is usually related to pressure, or even to the combination of pressure, friction and shear, most of the time, on bony prominences, especially in patients with reduced mobility. Moreover, factors such as age (newborn or elderly), inadequate nutrition, severe clinical conditions and skin moisture, among other conditions, can lead to the development of $\mathrm{PU}^{(3)}$.

Despite the advances achieved in PU prevention, national and international studies present a significant percentage of patients who develop PU. Internationally, in Intensive Care Units, this prevalence is between $14 \%$ to $42 \%$, different from the national scope, where incidence is approximately $22 \%$, with the most affected areas being the sacral region, with $47 \% \%^{(3-4)}$. Data from the National Pressure Ulcer Advisory Panel show that the prevalence of patients who develop PU in hospitals is around 15\% and the incidence is $7 \%$. In the United Kingdom, new cases of PU affect between $4 \%$ and $10 \%$ of patients admitted to hospitals ${ }^{(5)}$.

Nurses have gone to great lengths to prevent skin injuries, especially PU, which cause mutilation and keep the individual out of social life. In this context, it is understood that the assessment of patients who develop PU performed by nurses is fundamental, as they are professionals who are always close to patients and for a longer time ( 24 hours) and for being involved in the decision for the type of materials, products and technologies suitable for injury care.

There are several materials and products on the market with different indications for the different stages of PU treatment. These act to promote hygiene, debridement, decrease of infection, control of exudate, stimulation of granulation and protection of reepithelization. Dressings and/or coverings can be passive, interactive or hydroactive and bioactive ${ }^{(6-7)}$.

With regard to PU treatment, nurses have the autonomy to use the product and/or technology that they deem most appropriate. However, it is necessary that these professionals are equipped to do so. In this direction, the guiding question of this study was: which products/materials and technologies are effective for the treatment of patients who develop PU?

\section{OBJECTIVE}

To identify products/technologies for treating patients with pressure ulcers with an evidence level 1.

\section{METHODS}

\section{Type of study}

This is an integrative literature review according to the methodological stages recommended by Ganong ${ }^{(8)}$. This enables research of a scientific nature, with potential for information on research, in addition to gathering evidence on the practical application of science. Its purpose is to present a summary of evidence accumulated in primary research, discuss hypotheses, offer suggestions for new theoretical questions and identify necessary research ${ }^{(8)}$. These stages were developed as described in the sequence.

\section{Methodological procedures}

In the first stage, formulating the objective of the review and develop related questions to be answered by the reviewer or hypothesis to be tested, a research protocol was developed, which contains the objective and guiding question of study.

In the second stage, establishing criteria for the inclusion of studies in the review, it was established as inclusion criteria the selection of original and complete articles, with a quantitative approach, with level of evidence 1, published in the period from January 1, 2011 to May 6, 2016, in Portuguese, Spanish and English, and whose subjects were adults and/or older adults. It was decided to include only studies with level of evidence 1 because they present the best evidence. The time frame from 2011 to 2016 is justified by the authors' intention to include only current studies, that is, studies conducted in the last five years at the time of conducting this study. Articles published in the field of pediatrics and neonatology, duplicate publications, editorials, studies that included animals as subjects, letters and articles that did not address the theme were excluded.

The third stage, conducting a literature search, selecting examples if the number of studies is large, was carried out in partnership with a librarian. The following descriptors have been defined in Portuguese: Úlcera por Pressão, Curativos Oclusivos, Terapêuticas, Avaliação em Enfermagem, Cuidados de Enfermagem. Descriptors in English: Pressure Ulcer, Occlusive Dressings, Therapeutics, Nursing Assessment, Nursing Care. Descriptors in Spanish: Úlcera por Presión, Apósitos Oclusivos, Terapéutica, Evaluación en Enfermería, Atención de Enfermería.

The databases were defined, considering those with the largest number of studies published in the field of nursing and wound care, and the databases that aggregate the largest number of indexed journals. Thus, we used the Portal of the United States National Library of Medicine (PubMed), Scientific Electronic Library Online (SciELO), Virtual Health Library (VHL), US National Library of Medicine (MEDLINE), The 


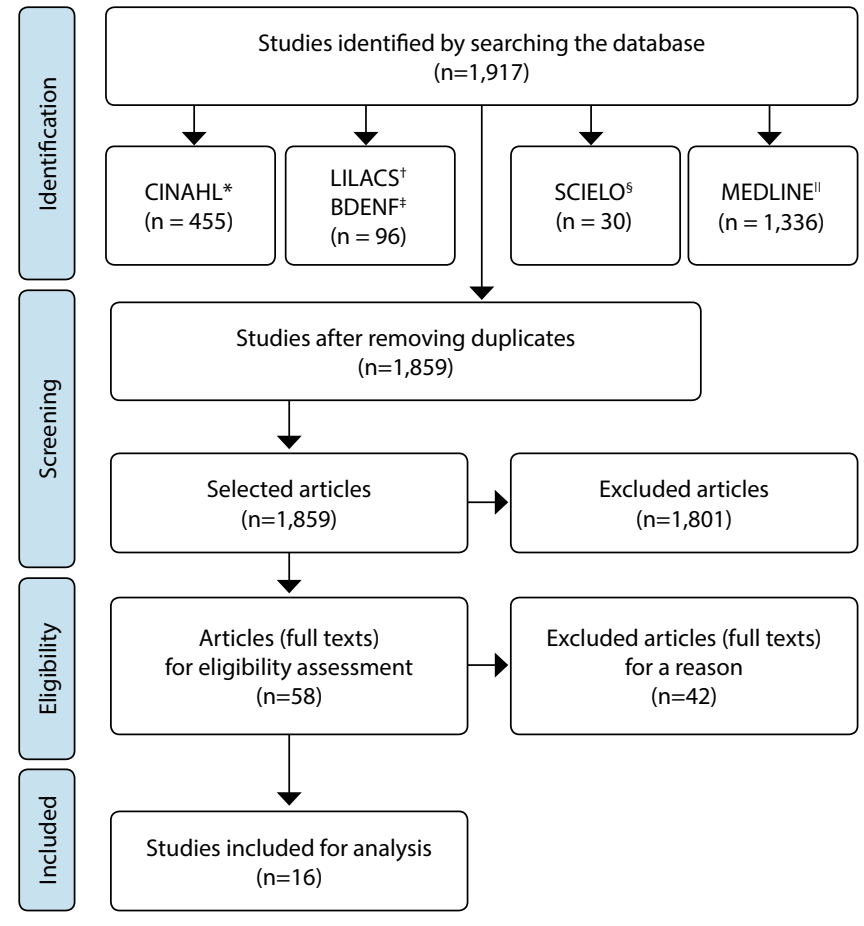

${ }^{*}$ CINAHL - The Cumulative Index to Nursing and Allied Health Literature; ${ }^{+}$LILACS - Latin American and Caribbean Literature in Health Sciences; ${ }^{\ddagger} B D E N F$ - Nursing Database; ${ }^{\S}$ SciELO - Scientific Electronic Library Online; "MEDLINE - National Library of Medicine

Figure 1 - PRISMA flowchart
Cumulative Index to Nursing and Allied Health Literature (CINAHL), Latin American \& Caribbean Health Sciences Literature (LILACS), Nursing Database (BDENF - Base de Dados de Enfermagem).

After defining the descriptors and the virtual libraries and databases, the search strategies were defined according to the virtual library or database, as specified in Chart 1.

After defining the previous steps, the authors searched the virtual libraries and databases, identifying the studies according to the criteria already presented. The specifications regarding the identification, screening, eligibility and included studies are presented in the PRISMA flowchart, as shown in Figure 1.

\section{Data collection and organization}

A chart was created to collect data from the identified studies, using the following variables: article code, article reference, country where the article was published, database, study design, results, recommendations, level of evidence and category formulated by the authors to which the article was directed. After reading the titles and abstracts, the articles were selected for reading in full, and this step was guided by the levels of evidence for effectiveness of level 1 proposed by The Joanna Briggs Institute ${ }^{(9)}$. Once the sample was defined, the data were collected, considering the results in relation to the products and technologies used in the studies, their action in PU, as well as the recommendations based on the findings of each study.

Chart 1 - Search strategies according to the virtual library or database

\begin{tabular}{|c|c|}
\hline $\begin{array}{l}\text { Virtual } \\
\text { library or } \\
\text { database }\end{array}$ & Search strategies \\
\hline SciELO & 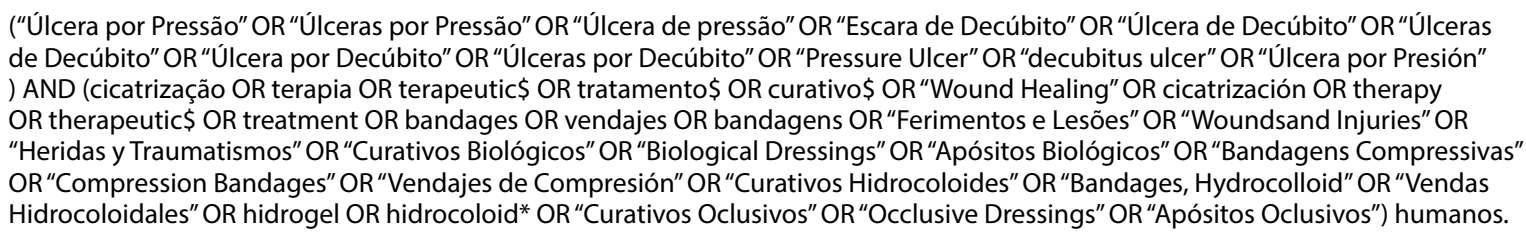 \\
\hline MEDLINE & 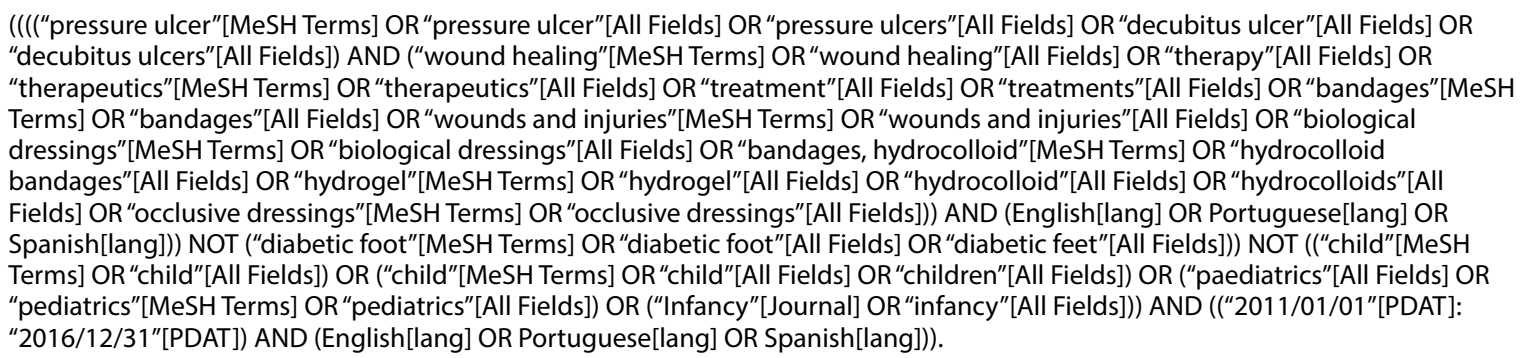 \\
\hline CINAHL & $\begin{array}{l}\text { (("pressure ulcer" OR "pressure ulcers" OR "decubitus ulcer" OR "decubitus ulcers") AND ( ("wound healing" OR "therapy" OR } \\
\text { "therapeutics" OR treatment* OR “bandages" OR "wounds and injuries" OR "biological dressings" OR "bandages, hydrocolloid" OR } \\
\text { "hydrocolloid bandages" OR "hydrogel" OR "hydrocolloid" OR "hydrocolloids" OR "occlusive dressings") ) ) NOT ( ("diabetic foot" OR } \\
\text { "diabetic feet) AND (child* OR pediatric* OR infancy)). }\end{array}$ \\
\hline $\begin{array}{l}\text { LILACS/ } \\
\text { BDENF }\end{array}$ & 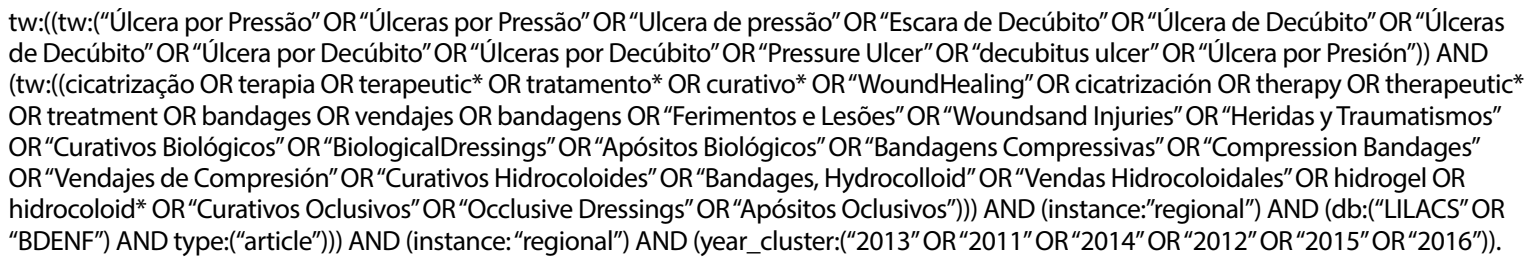 \\
\hline
\end{tabular}




\section{Data analysis}

Data analysis took place in a systematic way, considering the healing phases of PU, the types of tissue of PU and the stages of the lesion according to current literature ${ }^{(1-2,5)}$. After this stage, the findings of the studies were categorized according to the healing process and characteristics of the lesions. Five categories were developed: Topical therapy to promote healing; Alternative therapy to promote healing; Topical therapy to promote debridement; Topical therapy to minimize lesion contamination; Topical therapy to reduce lesion size. Finally, the results obtained were discussed, using other studies available in literature.

\section{RESULTS}

From searches carried out in libraries and virtual databases, 1,917 articles were found. After the analysis based on the inclusion and exclusion criteria, 1,897 were excluded. The 16 selected articles are all of evidence level 1.c and were read in full, 11 from
PubMed/MEDLINE and five from CINAHL. No article was selected for this study from the SciELO, LILACS and BDENF databases.

The results of the articles included in the study and presented in Chart 2 below were grouped by categories as mentioned above. The first category, Topical therapy to promote healing, presents six options of products/technologies that can be used alone or in combination: Membrane consisting of nanofibers of Poly-N-acetyl Glucosamine (sNAG) associated with Topical Negative Pressure Therapy in Wound (TPNF) (Study 02), Topical ointment sildenafil 10\% (Study 04), Aloe vera and Olive Oil (AVOO) (Study 05), 1\% atorvastatin ointment (Study 07), Lysine Hyaluronate (Lys-HL) (Study 16) as the main action, promoting microvascular perfusion and oxygen supply, stimulation contraction of the injured tissue and acceleration of healing, effective improvement in the stimulation of granulation tissue, in addition to promoting an effective PU regeneration. As for the main recommendations of these therapies/products, these concern professionals attention to the need for the presence of granulation tissue and the importance of classifying the stage of PU.

Chart 2 - Presentation of selected articles

\begin{tabular}{|c|c|c|c|c|c|}
\hline No & Study title & $\begin{array}{l}\text { Country } \\
\text { and year }\end{array}$ & $\begin{array}{l}\text { Design/ } \\
\text { sample size (n) }\end{array}$ & Interventions/Results & Recommendations \\
\hline 01 & $\begin{array}{l}\text { Effect of a wound } \\
\text { cleansing solution } \\
\text { on wound bed } \\
\text { preparation and } \\
\text { inflammation in } \\
\text { chronic wounds: a } \\
\text { single-blind } R C T^{(10)}\end{array}$ & $\begin{array}{l}\text { Italy } \\
2016\end{array}$ & $\begin{array}{l}\text { Randomized } \\
\text { controlled } \\
\text { clinical trial } \\
\text { (single blind) } \\
\mathrm{n}=289\end{array}$ & $\begin{array}{l}\text { Prontosan solution containing polyhexanide and betaine } \\
\text { (PPB) was used in comparison with Normal Saline Solution } \\
\text { (NSS) in patients randomized into two groups (PPB=143, } \\
\text { NNSS=146). Of those recruited, } 67 \% \text { had vascular injury to } \\
\text { the leg or mixed, } 25 \% \text { PU and others had traumatic wounds } \\
\text { with venous injury. The results confirmed the superiority } \\
\text { of the effectiveness of the PPB solution, as it promotes the } \\
\text { preparation of the wound bed, reduces inflammatory signs } \\
\text { and accelerates the healing of vascular leg and PU. }\end{array}$ & $\begin{array}{l}\text { There is superiority in } \\
\text { the effectiveness of PPB } \\
\text { solution versus NSS, and } \\
\text { suggests that, when used } \\
\text { with the best current } \\
\text { clinical practice, it reduces } \\
\text { inflammatory signs and } \\
\text { accelerates healing in PU. }\end{array}$ \\
\hline 02 & $\begin{array}{l}\text { Poly-N-acetyl } \\
\text { glucosamine } \\
\text { nanofibers for } \\
\text { negative-pressure } \\
\text { wound therapies }^{(11)}\end{array}$ & $\begin{array}{l}\text { Switzerland } \\
2015\end{array}$ & $\begin{array}{l}\text { Randomized } \\
\text { prospective } \\
\text { clinical trial } \\
n=1,020\end{array}$ & $\begin{array}{l}\text { The combination of Negative Pressure Wound Therapy } \\
\text { (NPWT) and application of Poly-N-acetyl Glucosamine (sNAG) } \\
\text { membranes in } 10 \text { patients with ischial or sacral PU compared } \\
\text { to isolated NPWT in } 10 \text { patients with isolated the same type } \\
\text { of lesions promoted healing due to an improved contraction } \\
\text { of the wound margins ( } \mathrm{p}=0.05 \text { ) without a change in the } \\
\text { epithelization of the wound. The application of thin sNAG } \\
\text { nanofiber membranes at the wound interface using NPWT } \\
\text { was safe and increased the action of NPWT, leading to better } \\
\text { wound healing due to stimulation of wound contraction. }\end{array}$ & $\begin{array}{l}\text { New studies should } \\
\text { confirm the preliminary } \\
\text { results obtained in this } \\
\text { pilot study in a greater } \\
\text { number of patients and } \\
\text { over a longer period of } \\
\text { observation. }\end{array}$ \\
\hline 03 & $\begin{array}{l}\text { Transdermal Wound } \\
\text { Oxygen Therapy on } \\
\text { Pressure Ulcer Healing: } \\
\text { A Single-Blind Multi- } \\
\text { Center Randomized } \\
\text { Controlled Tria/(12) }\end{array}$ & $\begin{array}{l}\text { Iran } \\
2015\end{array}$ & $\begin{array}{l}\text { Randomized } \\
\text { controlled } \\
\text { study } \\
n=100\end{array}$ & $\begin{array}{l}\text { Patients with PU stage II to IV in the sacral or sciatic areas, } \\
\text { admitted to Intensive Care Units (ICU) were randomly } \\
\text { assigned to the control or experimental groups. The } \\
\text { experimental group received Transdermal Oxygen Therapy } \\
\text { (TO) for } 12 \text { days. The condition of the wound was evaluated } \\
\text { seven times before the intervention as well as two, four, six, } \\
\text { eight, ten and twelve days after the intervention. After } 12 \text { days } \\
\text { of oxygen therapy, the number of patients with complete } \\
\text { healing in the experimental group was significantly higher } \\
\text { than in the control group and the total mean wound area in } \\
\text { the experimental group was significantly less than that of the } \\
\text { control group. }\end{array}$ & $\begin{array}{l}\text { TO is recommended as } \\
\text { an alternative strategy } \\
\text { to treat PU, as it can } \\
\text { effectively promote wouno } \\
\text { healing in PU patients. } \\
\text { However, more studies } \\
\text { are still needed to provide } \\
\text { more evidence about } \\
\text { the effectiveness of this } \\
\text { therapy. }\end{array}$ \\
\hline 04 & 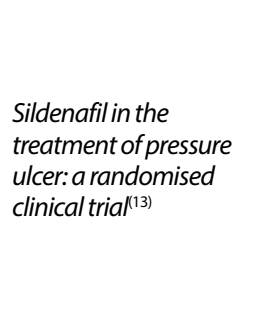 & $\begin{array}{l}\text { Iran } \\
2015\end{array}$ & $\begin{array}{l}\text { Randomized } \\
\text { controlled } \\
\text { clinical trial } \\
n=122\end{array}$ & $\begin{array}{l}\text { Patients admitted to ICU with PU stage I and II participated } \\
\text { in the study, who were randomly allocated to receive topical } \\
\text { ointment of sildenafil } 10 \% \text { or placebo daily. Wound healing } \\
\text { was assessed visually and photographically by altering } \\
\text { the wound score according to the two-digit Stirling scale. } \\
\text { Decreases in the stages of PU were significantly greater in the } \\
\text { group that used sildenafil compared to the placebo group ( } P \\
<0.001) \text {. In addition, the surface areas of ulcers in the sildenafil } \\
\text { group were significantly reduced compared to the control } \\
\left.\text { group on the } 14^{\text {th }} \text { day of intervention ( } P=0.007\right) \text {. }\end{array}$ & $\begin{array}{l}\text { Further studies are needed } \\
\text { to emphasize the role of } \\
\text { topical sildenafil in the } \\
\text { prevention or treatment of } \\
\text { PU in hospitalized patients, } \\
\text { as this was the first clinical } \\
\text { study to evaluate the } \\
\text { effects of topical sildenafil } \\
\text { on the cure of PU in } \\
\text { humans. }\end{array}$ \\
\hline
\end{tabular}




\begin{tabular}{|c|c|c|c|c|c|}
\hline $\mathbf{N}$ o & Study title & $\begin{array}{l}\text { Country } \\
\text { and year }\end{array}$ & $\begin{array}{l}\text { Design/ } \\
\text { sample size (n) }\end{array}$ & Interventions/Results & Recommendations \\
\hline 05 & $\begin{array}{l}\text { Comparative trial of } \\
\text { Aloe vera/olive oil } \\
\text { combination cream } \\
\text { versus phenytoin } \\
\text { cream in the treatment }_{\text {of chronic wounds }}^{(14)}\end{array}$ & $\begin{array}{c}\text { Australia } \\
2015\end{array}$ & $\begin{array}{l}\text { Double- } \\
\text { blinded } \\
\text { randomized } \\
\text { controlled trial } \\
\mathrm{n}=60\end{array}$ & $\begin{array}{l}60 \text { patients with chronic wounds ( } 41 \text { with PU, } 13 \text { with diabetic } \\
\text { wounds and six with venous lesions) were recruited and } \\
\text { randomized into two groups of } 30 \text {. After } 30 \text { days of standard } \\
\text { treatment with Aloe Vera and Olive Oil combination cream } \\
\text { (AVOO) or phenytoin cream, wound healing was assessed } \\
\text { using the Bates-Jensen evaluation tool. Although both } \\
\text { treatments reduced the initial score on the visual analog scale, } \\
\text { the effectiveness of AVOO was significantly higher ( } p<0.001) \text {. }\end{array}$ & $\begin{array}{l}\text { AVOO cream is } \\
\text { recommended, as it } \\
\text { significantly accelerates } \\
\text { the biological healing of } \\
\text { chronic wounds and helps } \\
\text { to reduce the intensity of } \\
\text { pain with a higher efficacy } \\
\text { compared to phenytoin } \\
\text { cream. The product must } \\
\text { be used for } 30 \text { days in } \\
\text { chronic lesions with the } \\
\text { presence of necrosis, } \\
\text { edema and pain. }\end{array}$ \\
\hline 06 & $\begin{array}{l}\text { Effectiveness of } \\
\text { platelet-rich plasma } \\
\text { and hyaluronic acid for } \\
\text { the treatment and care } \\
\text { of pressure ulcers }\end{array}$ & $\begin{array}{l}\text { USA } \\
2015\end{array}$ & $\begin{array}{l}\text { Randomized } \\
\text { clinical trial } \\
n=100\end{array}$ & $\begin{array}{l}\text { Patients with } 124 \text { Stage II-III PU were randomized to a control } \\
\text { group ( } n=25 \text { PU) for standard treatment or to groups of cases } \\
\text { for treatment with one ( } n=34 \text { PU) or two ( } n=25 \text { PU) doses of } \\
\text { Platelet-Rich Growth Factor (PRGF) from their own peripheral } \\
\text { blood, or two doses of PRGF plus hyaluronic acid }(H A)(n=40 \\
\text { PU). The greatest mean reduction }(80.4 \%) \text { was obtained } \\
\text { with the use of PRGF plus HA. Complete wound healing was } \\
\text { observed in } 32.0 \% \text { of PU treated with two doses of PRGF ( } p \\
<0.002) \text { and in } 37.5 \% \text { of those treated with two doses of PRGF } \\
\text { plus HA }(p<0.004) \text {. }\end{array}$ & $\begin{array}{l}\text { Applications with two } \\
\text { doses of PRGF plus HA } \\
\text { can provide better results. } \\
\text { Further investigation on } \\
\text { the use of this strategy is } \\
\text { suggested. }\end{array}$ \\
\hline 07 & $\begin{array}{l}\text { Efficacy of topical } \\
\text { atorvastatin for the } \\
\text { treatment of pressure } \\
\text { ulcers: a randomized } \\
\text { clinical tria(16) }^{16}\end{array}$ & $\begin{array}{l}\text { Iran } \\
2014\end{array}$ & $\begin{array}{l}\text { Double-blind } \\
\text { placebo- } \\
\text { controlled } \\
\text { randomized } \\
\text { clinical trial } \\
\mathrm{n}=104\end{array}$ & $\begin{array}{l}\text { Critical patients admitted to the medical-surgical ICU with } \\
\text { stage I or II PU participated in the study, classified according } \\
\text { to the two-digit Stirling Scale. In } 51 \text { patients, topical 1\% } \\
\text { atorvastatin ointment (atorvastatin group) was used and in } \\
53 \text { patients, placebo ointment (control group) was applied } \\
\text { once daily to the lesion for } 14 \text { days, in addition to the standard } \\
\text { treatment for PU. The application of } 1 \% \text { atorvastatin ointment } \\
\text { significantly accelerated the healing of PU in stages I or II. }\end{array}$ & $\begin{array}{l}\text { Pay attention to the PU } \\
\text { stage. } \\
1 \% \text { atorvastatin ointment } \\
\text { must be used to accelerate } \\
\text { the healing process in PU } \\
\text { in critically ill patients in } \\
\text { stages I and II. }\end{array}$ \\
\hline 08 & $\begin{array}{l}\text { Effects of } \\
\text { polydeoxyribonucleotide } \\
\text { in the treatment of } \\
\text { pressure ulcers }^{(17)}\end{array}$ & $\begin{array}{l}\text { Korea } \\
2014\end{array}$ & $\begin{array}{l}\text { Randomized } \\
\text { controlled } \\
\text { clinical trial } \\
\text { (pilot study) } \\
\mathrm{n}=30\end{array}$ & $\begin{array}{l}\text { The study included patients hospitalized between } 18 \text { and } 85 \\
\text { years old, with PU above stage II, with lesions not exceeding } 20 \\
\mathrm{~cm}^{2} \text { horizontally, without secondary infection or local infection } \\
\text { and with delay in the treatment of PU for more than two } \\
\text { weeks. The effects of polydeoxyribonucleotide (PDRN) were } \\
\text { compared over time between an experimental group ( } \mathrm{n}=11 \text { ) } \\
\text { and a control group ( } \mathrm{n}=12 \text { ). After the four-week treatment } \\
\text { period, PDRN therapy was found to significantly reduce lesion } \\
\text { size and the PUSH score (healing). The results indicate that } \\
\text { PDRN can positively modify the wound healing process in PU, } \\
\text { its use can improve the clinical results of patients and decrease } \\
\text { the need for additional therapies or hospitalization. }\end{array}$ & $\begin{array}{l}\text { An ampoule ( } 3 \mathrm{ml} \text { of } 5.625 \\
\text { mg) intramuscularly must } \\
\text { be administered for five } \\
\text { days for two weeks, and } \\
\text { then perilesionally ( } 1 \\
\text { ampoule, } 3 \text { ml, } 5.625 \mathrm{mg} \text {, } \\
\text { twice a week) for } 4 \text { weeks. } \\
\text { In future studies, the } \\
\text { time must be extended } \\
\text { to observe and verify the } \\
\text { complete healing of PU. }\end{array}$ \\
\hline 09 & $\begin{array}{l}\text { High-Voltage Pulsed } \\
\text { Current Electrical } \\
\text { Stimulation in Wound } \\
\text { Treatment }^{(18)}\end{array}$ & $\begin{array}{l}\text { Poland } \\
2014\end{array}$ & $\begin{array}{l}\text { Randomized } \\
\text { controlled } \\
\text { prospective } \\
\text { study } \\
\mathrm{n}=42\end{array}$ & $\begin{array}{l}\text { Participants in the study were elderly people aged } 71 \text { to } \\
95 \text { years, with wounds that did not respond to previous } \\
\text { treatment for at least four weeks. They were randomly } \\
\text { assigned to the treatment group (TG) ( } 20 \text { with } 21 \mathrm{PU} \text { ) or } \\
\text { control group ( } 22 \text { with } 23 \mathrm{PU} \text { ). All received standard wound } \\
\text { care. TG was additionally supplied with High Frequency } \\
\text { Ultrasound (HFUS; MHz) ( } 1 \mathrm{MHz}, 0.5 \mathrm{~W} / \mathrm{cm}^{2}, 20 \% \text { duty cycle, } \\
1-3 \text { minutes/cm²; one session per day, } 5 \text { days a week). Patients } \\
\text { were monitored for six weeks or until the wounds were closed. } \\
\text { The study showed that therapy with HFUS can reduce the } \\
\text { wound surface area of PU, more effectively than standard } \\
\text { treatment alone. }\end{array}$ & $\begin{array}{l}\text { PU in stage II and III, HFUS } \\
\text { (MHz) for one to } 3 \text { minutes } \\
\text { must be used, once a day, } \\
\text { for six weeks. } \\
\text { More research is needed, } \\
\text { particularly to establish } \\
\text { how ultrasound influences } \\
\text { the healing of stage III and } \\
\text { IV PUs. }\end{array}$ \\
\hline 10 & $\begin{array}{l}\text { Randomised controlled } \\
\text { trial evaluating the } \\
\text { efficacy of wrap } \\
\text { therapy for wound } \\
\text { healing acceleration in } \\
\text { patients with NPUAP } \\
\text { stage Il and III pressure } \\
\text { Ulcer }^{(19)}\end{array}$ & $\begin{array}{c}\text { Japan } \\
2012\end{array}$ & $\begin{array}{l}\text { Multicenter, } \\
\text { prospective, } \\
\text { randomized, } \\
\text { open-label } \\
\text { blind trial } \\
\mathrm{n}=66\end{array}$ & $\begin{array}{l}\text { The } 66 \text { oldest patients admitted to } 15 \text { hospitals, with stage } \\
\text { II or III PU, participated in the study. } 31 \text { were divided into } \\
\text { the conventional TG and } 35 \text { into the Wrap Therapy group } \\
\text { (polyethylene sheets, such as food wraps). The estimated } \\
\text { average period until healing was } 57.5 \text { days in the control } \\
\text { group and } 59.8 \text { in the therapy group. Due to the extent of PU } \\
\text { infiltration, the average period until healing was } 16 \text { days in the } \\
\text { control group and } 18.8 \text { in the therapy group for stage II PU, } \\
\text { and } 71.8 \text { days in the control group versus } 63.2 \text { in the stage III } \\
\text { PU therapy group. There was no statistical significance in the } \\
\text { difference in the scores of the Pressure Ulcer Scale for Healing. }\end{array}$ & $\begin{array}{l}\text { Wrap Therapy has been } \\
\text { found to be not harmful } \\
\text { and has equivalent or } \\
\text { better efficacy compared } \\
\text { to conventional } \\
\text { treatments. } \\
\text { It may be possible to } \\
\text { consider Wrap Therapy as } \\
\text { an alternative option in } \\
\text { primary care as a simple } \\
\text { and inexpensive treatment } \\
\text { that can also be applied in } \\
\text { the elderly. }\end{array}$ \\
\hline
\end{tabular}




\begin{tabular}{|c|c|c|c|c|c|}
\hline $\mathbf{N}$ o & Study title & $\begin{array}{l}\text { Country } \\
\text { and year }\end{array}$ & $\begin{array}{l}\text { Design/ } \\
\text { sample size (n) }\end{array}$ & Interventions/Results & Recommendations \\
\hline 11 & $\begin{array}{l}\text { A comparison of } \\
\text { collagenase to } \\
\text { hydrogel dressings } \\
\text { in maintenance } \\
\text { debridement and } \\
\text { wound closure }^{(20)}\end{array}$ & $\begin{array}{l}\text { USA } \\
2012\end{array}$ & $\begin{array}{l}\text { Prospective, } \\
\text { randomized } \\
\text { controlled } \\
\text { clinical trial } \\
\mathrm{n}=15\end{array}$ & $\begin{array}{l}\text { We included } 15 \text { critical patients who successfully completed } \\
\text { phase } 1 \text { of the study from the moment of necrotic tissue } \\
\text { debridement. Daily dressing changes with Hydrogel or } \\
\text { Collagenase were performed, followed by a standard } \\
\text { semiocclusive dressing to evaluate wound healing parameters } \\
\text { and its closure from the initial record to the } 84^{\text {th }} \text { day. In the } \\
\text { aggregation of data of phase } 1 \text { and phase } 2 \text {, a difference in } \\
\text { closing rates at the end of the study, } 69 \% \text { (collagenase) vs. } 21 \% \\
\text { (hydrogel), was statistically significant ( } P=0.0213 \text { ). Collagenase } \\
\text { was more effective in the closure rates since the beginning of } \\
\text { PU. }\end{array}$ & $\begin{array}{l}\text { Collagenase or hydrogel } \\
\text { can be used to maintain } \\
\text { debridement and } \\
\text { complete wound closure } \\
\text { when used in conjunction } \\
\text { with a validated predictive } \\
\text { wound healing tool that } \\
\text { closely monitors therapy. }\end{array}$ \\
\hline 12 & $\begin{array}{l}\text { Eradication of } \\
\text { methicillin-resistant } \\
\text { Staphylococcus } \\
\text { aureus in pressure } \\
\text { ulcers comparing } \\
\text { a polyhexanide- } \\
\text { containing cellulose } \\
\text { dressing with } \\
\text { polyhexanide swabs } \\
\text { in a prospective } \\
\text { randomized study }\end{array}$ & $\begin{array}{l}\text { USA } \\
2012\end{array}$ & $\begin{array}{l}\text { Randomized } \\
\text { prospective } \\
\text { clinical trial } \\
n=30\end{array}$ & $\begin{array}{l}\text { The study included } 30 \text { hospitalized patients ( } n=15 / n=15) \text { who } \\
\text { had PU containing methicillin-resistant Staphylococcus aureus } \\
\text { (MRSA) and who did not respond to wound disinfection after } \\
\text { a two-week washout period. For the control group, cleaning } \\
\text { was performed with polyhexanide swabs ( } 20 \text { minutes), after } \\
\text { which a foam dressing was applied. The study group received } \\
\text { a cellulose dressing containing Polyhexanide. On day } 7 \text {, in } \\
\text { the control group, six out of } 15 \text { ( } 40 \% \text { ) have achieved the } \\
\text { eradication of MRSA. For the study group, there were } 13 \text { of } \\
\text { the } 15 \text { ( } 86.67 \%) \text { who had had MRSA eradication. On day } 14 \text {, in } \\
\text { the control group, there were } 10 \text { of the } 15 \text { ( } 66.67 \%) \text { who had } \\
\text { MRSA eradication, compared to the study group, in which } 15 \\
\text { out of } 15 \text { ( } 100 \% \text {; } P<0.05 \text { ) had MRSA eradicated. Disinfection } \\
\text { of wounds with polyhexanide was successful in both groups, } \\
\text { showing superior results for the study group. }\end{array}$ & $\begin{array}{l}\text { The product is } \\
\text { recommended for } \\
\text { use in PU with the } \\
\text { presence of pathogenic } \\
\text { microorganisms. The } \\
\text { product should remain } \\
\text { in the lesion bed for } 20 \\
\text { minutes before using the } \\
\text { dressing of choice. This } \\
\text { is a product proposed as } \\
\text { an effective method to } \\
\text { disinfect contaminated } \\
\text { wounds. }\end{array}$ \\
\hline 13 & $\begin{array}{l}\text { Using high-voltage } \\
\text { electrical stimulation } \\
\text { in the treatment of } \\
\text { recalcitrant pressure } \\
\text { ulcers: results of a } \\
\text { randomized, controlled } \\
\text { clinical study }\end{array}$ & $\begin{array}{l}\text { Poland } \\
2012\end{array}$ & $\begin{array}{l}\text { Prospective, } \\
\text { randomized, } \\
\text { controlled } \\
\text { clinical trial } \\
\mathrm{n}=50\end{array}$ & $\begin{array}{l}\text { The effect of High Voltage Electrical Stimulation (HVES) } \\
\text { was evaluated in patients with non-healing PU in the lower } \\
\text { extremities, with stages II and III. Twenty-six patients were } \\
\text { included in the TG and } 24 \text { in the control group. All of them } \\
\text { received standard supportive care and topical treatments } \\
\text { covered with wet to moist dressings and were followed up } \\
\text { until healing for a maximum of six weeks. Patients allocated in } \\
\text { the treatment arm of the study also received HVES ( } 100 \mathrm{~V} ; 100 \\
\mu \text { s; } 100 \mathrm{~Hz} \text { ) continuously for } 50 \text { minutes, once a day, } 5 \text { times a } \\
\text { week. Wound area, linear measurement, wound volume and } \\
\text { granulation tissue changes were significantly higher in the TG } \\
\text { than in the control group from the second week of treatment. } \\
\text { The change in the area of week six was } 88.9 \% \text { in treatment } \\
\text { and } 44.4 \% \text { in the control group ( } P=0.00003 \text { ). }\end{array}$ & $\begin{array}{l}\text { Recommended in PU } \\
\text { in stage II, III and IV with } \\
\text { the presence of purulent } \\
\text { exudate. } 100 \mathrm{~V} \text { should } \\
\text { be used once a day, } 5 \\
\text { times a week, for six } \\
\text { weeks, mainly in patients } \\
\text { requiring stimulation } \\
\text { and acceleration of the } \\
\text { granulation phase. New } \\
\text { research to compare the } \\
\text { effectiveness of using } \\
\text { combined or anodic } \\
\text { cathodic stimulation or } \\
\text { alone and to determine } \\
\text { the ideal duration of these } \\
\text { two types of electrical } \\
\text { stimulation must be } \\
\text { conducted. }\end{array}$ \\
\hline 14 & $\begin{array}{l}\text { The efficacy of silver } \\
\text { mesh dressing } \\
\text { compared with silver } \\
\text { sulfadiazine cream } \\
\text { for the treatment of } \\
\text { pressure ulcers }^{(23)}\end{array}$ & $\begin{array}{c}\text { Thailand } \\
2011\end{array}$ & $\begin{array}{l}\text { Randomized } \\
\text { prospective } \\
\text { clinical trial } \\
n=40\end{array}$ & $\begin{array}{l}\text { Patients with stage III or IV PU who were randomly divided } \\
\text { into two groups of } 20 \text { participated in the study. The wound } \\
\text { beds were covered with silver sulfadiazine cream in the } \\
\text { control group, and dressing with silver mesh was used in } \\
\text { the experimental group. Wound reduction was higher in the } \\
\text { experimental group than in the control group.9The cost of } \\
\text { treatment using silver mesh was significantly cheaper than } \\
\text { using silver sulfadiazine cream. Silver dressing is one of the } \\
\text { options for PU treatment, with good cure rate, minimal care } \\
\text { and lower overall cost. }\end{array}$ & $\begin{array}{l}\text { It must be used in PU in } \\
\text { stages III and IV, directly on } \\
\text { the PU bed, having gauze } \\
\text { as secondary dressing. } \\
\text { The mesh should be } \\
\text { changed every three days } \\
\text { or after dressing saturation. } \\
\text { Silver mesh dressing } \\
\text { provided infection control } \\
\text { and promotes the wound } \\
\text { healing process. }\end{array}$ \\
\hline 15 & $\begin{array}{l}\text { Faster wound healing } \\
\text { with topical negative } \\
\text { pressure therapy } \\
\text { in difficult-to-heal } \\
\text { wounds: a prospective } \\
\text { randomized controlled } \\
\text { trial(24) }^{(24)}\end{array}$ & $\begin{array}{c}\text { The } \\
\text { Netherlands } \\
2011\end{array}$ & $\begin{array}{l}\text { Randomized } \\
\text { clinical trial } \\
n=24\end{array}$ & $\begin{array}{l}\text { Patients were randomly assigned for treatment with topical } \\
\text { negative pressure therapy or conventional dressing treatment } \\
\text { with sodium hypochlorite. The mean treatment time for a } 50 \% \\
\text { reduction in lesion volume in the topical negative pressure } \\
\text { group was two weeks compared to } 3.5 \text { weeks in the sodium } \\
\text { hypochlorite group. Topical negative pressure has resulted in } \\
\text { wound healing almost twice as fast as treatment with sodium } \\
\text { hypochlorite and is safe in patients with difficult-to-heal } \\
\text { wounds. }\end{array}$ & $\begin{array}{l}\text { It must be used in stage } \\
\text { IV PU and adjusted to the } \\
\text { dressing according to } \\
\text { the lesion size. Negative } \\
\text { pressure of } 125 \mathrm{mmHg} \\
\text { is recommended three } \\
\text { times a week in wounds } \\
\text { requiring reduced lesion } \\
\text { volume. The average } \\
\text { treatment time is four } \\
\text { weeks. }\end{array}$ \\
\hline
\end{tabular}




\begin{tabular}{|c|c|c|c|c|c|}
\hline No & Study title & $\begin{array}{l}\text { Country } \\
\text { and year }\end{array}$ & $\begin{array}{l}\text { Design/ } \\
\text { sample size (n) }\end{array}$ & Interventions/Results & Recommendations \\
\hline 16 & $\begin{array}{l}\text { Effect of lysine } \\
\text { hyaluronate on the } \\
\text { healing of decubitus } \\
\text { ulcers in rehabilitation } \\
\text { patients }^{(25)}\end{array}$ & $\begin{array}{l}\text { Italy } \\
2011\end{array}$ & $\begin{array}{l}\text { Randomized } \\
\text { controlled } \\
\text { double-blind } \\
\text { study } \\
\mathrm{n}=50\end{array}$ & $\begin{array}{l}\text { Fifty patients hospitalized with PU were divided into three } \\
\text { groups according to the stage of the lesion (stage } 1 \text { : erythema } \\
\text { and edema; stage } 2 \text { : cutaneous destruction of all thicknesses; } \\
\text { stage 3: destruction of subcutaneous tissue) and randomized } \\
\text { to receive Lysine Hyaluronate (Lys-HL) or sodium hyaluronate } \\
\text { (SH). Ulcer reduction was higher in all Lys-HL groups than in } \\
\text { SH groups. In stage } 1 \text { patients, there had been a reduction in } \\
\text { lesion size of } 90 \% \text { and } 70 \% \text { in the groups allocated to Lys-HL } \\
\text { and SH, respectively ( }(P<0.05) \text {. In stage } 2 \text { patients, } 70 \% \text { and } \\
40 \% \text { of lesion size reductions were observed in the Lys-HL and } \\
\text { SH groups, respectively }(\mathrm{P}<0.02) \text {. In stage } 3 \text { patients, } 71 \% \text { and } \\
29 \% \text { of lesion size reductions were observed in the Lys-HL } \\
\text { and SH groups, respectively }(\mathrm{P}<0.01) \text {. The regression time of } \\
50 \% \text { of lesion size was shorter in all Lys-HL groups than in SH } \\
\text { groups }(\mathrm{P}<0.05) \text {. }\end{array}$ & $\begin{array}{l}\text { Apply the product } \\
\text { directly to PU according } \\
\text { to stage II and III. The use } \\
\text { of Lys-HA in the healing } \\
\text { process of decubitus } \\
\text { ulcers provides improved } \\
\text { efficacy in relation to SH } \\
\text { in hospitalized patients, } \\
\text { suggesting its use from the } \\
\text { early stages of ulceration. } \\
\text { Lys-HA is recommended to } \\
\text { decrease the lesion area by } \\
\text { stimulating angiogenesis. }\end{array}$ \\
\hline
\end{tabular}

In the second category, Alternative therapy to promote healing, it was identified that alternative therapies are frequently used in injury treatment, with the purpose of helping to promote healing, increasing cellular activity, stimulating angiogenesis and neoangiogenesis, regulating and modulating moisture in PU bed.

Six technologies were identified as alternative therapies in the studies evaluated, namely: OT (Study 03), PRGF (Study 06), PDRN (Study 08), HFUS (MHz) (Study 09), Wrap therapy (Study 10) and HVES (Study 13). The main recommendation regarding the use of these therapies is based on the need to assess the tissue of the lesion and the presence of exudate. Each product/therapy has its specific recommendations for its use in PU.

The third category, Topical therapy to promote debridement, presented two products, i.e., hydrogel and collagenase with the main action of promoting the moisture of dead tissue and, thus, removing this tissue through autolytic debridement, since through from an exogenous source of moisture the body's own physiological mechanisms achieve wound repair. Only one study was identified (Study 11). The recommendation to use this product involves the need to constantly evaluate how long this PU remains moist. If it is noticed that there is no more moisture in the lesion, it is necessary that the product be reapplied.

The fourth category, Topical therapy to minimize lesion contamination, presents the products to be used in contaminated PU. Three products/technologies were identified, namely: PPB (Study 01), Dressing with silver mesh (Study 14) and cellulose dressing containing polyhexanide (Study 12).

A contaminated lesion slows down the healing process, since the human body is unable to act on wound healing and infection. The action of the products is directly related to providing infection control, reducing inflammatory signs and accelerating healing in PU.

The fifth category, Topical therapy to reduce lesion size, indicates treatment with topical negative pressure therapy (Study 15) to accelerate wound healing and is safe for use in patients with difficult to heal wounds. This therapy can be used in stage IV $\mathrm{PU}$, with a negative pressure of $125 \mathrm{mmHg}$, three times a week, in wounds whose lesion is large is recommended. Average treatment time is four weeks.

The products presented here and their level of evidence are suggestions that can serve as a guide for the situations encountered in daily life with regard to PU treatment. It is worth mentioning that the decision to use each product and at each stage, except for systemic medications, is made by nurses, in harmony with the service where they work and also considering the protocols already implemented in each institution.

\section{DISCUSSION}

The study presents evidence for the treatment of patients who develop PU. All studies included in the review are based on randomized controlled trials and, therefore, all have level of evidence 1. $c^{(9)}$. Scientific evidence supports, strengthens and makes care more effective and safer. Through randomized controlled studies it is possible to control variables related to patient characteristics, comorbidities, use of drugs, among others.

Nurses must provide patients with assistance based on scientific evidence, and based on a holistic and continuous assessment, considering the factors that interfere with healing and the individualized and daily prescription regarding the necessary product and/ or technology. These can be varied, according to the evolutionary moment of the healing process ${ }^{(26)}$. Along with this, the nurse has a great contribution in the care of patients with $\mathrm{PU}$, in the sense of seeking to integrate multidisciplinary groups in order to support and subsidize the treatment of injuries, especially, including patient nutrition and the minimization of pathogens in $\mathrm{PU}^{(2,7)}$.

Studies show evidence based on new dressing technologies, and it is essential that professionals, especially nurses, are always up-to-date and able to consider the ideal material, product and/or technology to use in PU, according to each stage of the injury ${ }^{(27-29)}$, which is capable of promoting faster wound repair, reducing contamination/infection, protecting against dirt and providing comfort to patients, less pain, faster changes, lower cost and greater benefit ${ }^{(30)}$.

PIs are considered an important problem, both in primary care and at the hospital level, cause great economic impact, and substantially increase hospital costs, the number of hours of the nursing staff, length of stay, the risk of infections, among others $^{(6-7,26-31)}$. Additionally, they provide serious damage to the emotional and physical health of patients and family members ${ }^{(32)}$. A study carried out in 2013 with 40 patients in a palliative and long-term care unit in a hospital in Minas Gerais showed that the 
cost of treatment was estimated at around $\mathrm{R} \$ 36,629.95$ (around US\$6,660,00) per patient/month, with the cost for the hospital rises, mainly, if the resources regarding the use of available materials, products and technologies are not used properly ${ }^{(6,31)}$.

During information analysis, it was identified that certain products are effective in accelerating the healing process in clean lesions, providing an effective reduction of non-viable tissue, in addition to promoting the formation of granulation tissue. Some products such as AVOO, atorvastatin ointment (1\%) and Sildenafil ointment (10\%) showed a strong tendency to accelerate the healing process, in addition to significantly reducing the PU area.

Regarding atorvastatin ointment (1\%) and Sildenafil ointment (10\%), no other studies using these products were found. However, olive oil was mentioned in a study, showing that because it is often more affordable, it can be a substitute for Essential Fatty Acids and also be used in prevention, maintaining skin hydration ${ }^{(32)}$.

Yet another study described that olive oil improves pressure wound healing by reducing inflammatory cells and increasing the number of blood vessels, promoting dermal reconstruction and wound closure ${ }^{(33)}$. The formation of new blood vessels, increased granulation tissue and the amount of synthesized collagen are essential for the healing process to occur ${ }^{(11,22,34)}$.

Another relevant finding in the present study on healing and reducing the dimensions of the lesion is related to the use of alternative therapies in the healing process of PU. Six products related to alternative therapy were identified, showing that there is a tendency for scholars to investigate new technologies capable of assisting and/or accelerating the healing process.

One of the most found evidences is related to the use of ultrasound, providing the stimulation of the activity of macrophages and fibroblasts in the lesion. This increases the oxygen support, in addition to providing modulation of the lesion. Most of it is used in more extensive PU, as in stages III and IV. The importance of careful assessment of the injury by nurses is emphasized, since there are recommendations to avoid the use of this technology in infected lesions and with the presence of exudate ${ }^{(1)}$.

HVES and HFUS ( $\mathrm{MHz}$ ) provide a significant reduction in the PU area. Products that speed up the healing process optimize the recovery of patients, thus shortening the length of hospital stay and also preventing other injuries. At the level of primary care, it also reduces the cost of treatment for families, bringing well-being as a whole and a better quality of life for patients ${ }^{(18,35)}$. A prospective randomized clinical trial performed on patients with chronic diabetic foot ulcers showed that continuous TO can facilitate healing, reversing the inflammatory process ${ }^{(36)}$.

It is worth mentioning that the studies presented bring the evaluation of the lesion as the main guideline before opting for any product and/or technology. It is essential that nurses know patients' history, the factors related to PU, as well as the characteristics of this injury. The choice of product depends on the type of tissue found in the lesion bed $^{(37)}$.

In this sense, it is important that nurses carry out a comprehensive assessment of patients and a previous and thorough assessment of PU, considering the most affected regions (sacral, trochanteric, calcaneus, sciatic region, among others), lesion size (length, width, depth and area), edges (whether adhered or not), the presence of maceration, tunnels or fistulas, the presence of exudate (quantity, whether absent or low, moderate or abundant) and its appearance (serous or purulent, thick or fluid), color and signs of infection (odor, if absent or foul). Still, it is necessary to evaluate the tissue characteristic, considering whether there is presence of slough, granulation tissue and/or necrosis, describe the skin around the lesion, paying attention to hyperchromia, flushing, heat and perfusion, as well as the healing phase and the stage of $\mathrm{PU}^{(37-38)}$.

The present study also points to evidence regarding the preparation of the wound bed before using products that can accelerate the healing process so that wound bed preparation is an established measure in the treatment of injuries. Therefore, minimizing factors that interfere with healing, such as necrotic tissue, exudate, and bacterial and cellular dysfunction, leads to optimal results regarding wound healing ${ }^{(12,20)}$. Therefore, a correct evaluation includes the observation of the need to eliminate necrotic tissue, bacterial load, biofilms, edema and exudate, promoting the formation of granulation tissue. In some cases, debridement is an essential stage to start the healing process.

Despite the importance of debridement of non-viable tissue from the lesion, the results of this study show only two products, collagenase and hydrogel, which act in the maintenance of debridement. Hydrogel is effective because it is composed of $77.7 \%$ water, carboxymethylcellulose and propylene glycol. This compound assists in cell migration facilitated by product moisture, providing debridement. Hydrogel presents itself as an effective product for keeping the wound bed moist, facilitating cellular rehydration and debridement ${ }^{(20,39-40)}$. As for collagenase, a study has found that it has been more effective than hydrogel in closing $\mathrm{PU}^{(17)}$.

Moisture is essential for healing, it facilitates epithelialization and the formation of collagen. Dry wounds lose the fluid rich in growth factors that stimulate angiogenesis and, thus, become slower in healing due to deficiency of blood vessels and the accumulation of collagen in the crust. Dryness and crusts hinder cell migration, as it needs moisture, and epithelial cells migrate on and around the wound surface ${ }^{(1)}$.

When removing unviable, devitalized or colonized tissues, the stimulation of the wound edges is stimulated. The use of products that favor the humid environment and the formation of macrophages that destroy bacteria and remove devitalized tissue should be proposed ${ }^{(2,41)}$.

The unviable tissue triggers the release of enzymes, increasing capillary permeability and the absorption of toxins, causing loss of fluids. Furthermore, dead tissue is an important culture medium, increasing bacterial growth and altering cell function. The removal of necrotic tissue from the wound bed facilitates the contraction of the lesion and healing ${ }^{(42)}$.

As for the colonization of pathogens, in several situations, PUs are susceptible to showing signs of infection with erythema and purulent exudate. In this case, the presence of contamination is not ruled out, as this is generally related to the fact that patients have low immunity, inadequate nutrition, diabetes and/or other comorbidities, or is colonized with antibiotic-resistant bacteria in systemic therapy.

Regarding topical therapy to minimize PU contamination, three products were identified in the present study. The actions are aimed at promoting the removal of pathogens, infection control and reduction of inflammatory signs, accelerating the wound healing 
process. Minimizing or preventing the risk of pathogens in the lesion is essential for the wound healing process to occur ${ }^{(43-44)}$.

Extrinsic factors, aggressive agents and non-viable tissues can delay the entire healing process of $\mathrm{PU}$, in addition to causing tissue malnutrition ${ }^{(1-2)}$. There is a need to remove or decrease the barriers that hinder the healing process, one of the barriers being microorganisms ${ }^{(2,41)}$. Bacteria impose biological and metabolic load on the lesion, delay or prevent tissue restoration as they cause toxicity and decrease the nutrients available to scar cells ${ }^{(1,42)}$.

Thus, it is essential that PU are treated with specific and appropriate products that can assist in the treatment and control of infection in the lesion. In this study, there is evidence in relation to the PPB that must remain in the lesion bed for 10 to 20 minutes, and the mesh containing silver ions, which can remain up to seven days, depending on the amount of exudate presented. In other studies, it is perceived the effectiveness in reducing inflammatory signs and accelerating healing when using Prontosan ${ }^{(10,21,45)}$.

The evidence presented in this study is relevant to the nurse, in order to assist this professional in qualified and effective assistance in PU treatment. In this sense, it is understood that the nurse must seek a look turned, first, to patients, followed by a careful assessment of PU. Based on this premise, the result will certainly be an effective and quality assistance ${ }^{(46-47)}$.

It is essential that nurses and the nursing/health team appropriate and systematically use care protocols for both PU prevention and treatment, considering this to be a fundamental tool for the adequate use of resources and materials, products and technologies available in each institution and/or health service, which is also corroborated by other authors when they mention that the protocols, when used systematically, are fundamental tools in PU incidence control ${ }^{(48)}$.

\section{Study limitations}

The study is limited by the time frame, since only studies published between January 1, 2011 and May 6, 2016 were included in the review.

\section{Contributions to nursing, health, and public policy}

The results presented are valuable contributions for nurses who are managers of care for patients who develop PU and who need adequate care and treatment for each case, including treatment planning, PU care and constant evaluation. Based on this evidence, nurses will have more options to support their practice, especially regarding products related to the healing process.

\section{FINAL CONSIDERATIONS}

Through this study it was possible to identify effective products and technologies for PU treatment at different stages of the evolution of the lesions and according to their characteristics and the healing process. Sixteen studies were identified, all based on randomized controlled trials and which present strong evidence for the use of these products and/or technologies, which is the main contribution of the present study. All identified products/ technologies can be used safely and effectively in PU treatment.

The 17 products/technologies mentioned in this article point to evidence for the healing process, promoting debridement, minimizing lesion contamination and reducing lesion size to accelerate wound healing. Six products/technologies were presented as topical therapy and six technologies as alternative therapy that act to promote healing, two products that act to promote debridement, three products/technologies that act to minimize contamination of the lesion and one product/technology to reduce lesion size, which also acts to promote healing.

\section{SUPPLEMENTARY MATERIAL}

The article is the result of the Master's Thesis entitled: Construction of a nursing care guide for the treatment of patients with pressure injuries, available in the Institutional Repository of the University Library of the Universidade Federal de Santa Catarina, at the link: https://repositorio. ufsc.br/handle/123456789/181596.

\section{REFERENCES}

1. Domansky RC, Borges EL. Manual para prevenção de lesões de pele: recomendações baseadas em evidências. Rio de Janeiro: Editora Rubio; 2014.

2. Malagutti W. Feridas: conceitos e atualidades. 2a ed. São Paulo: Martinari; 2015.

3. Byrne J, Nichols P, Sroczynski M, Stelmaski L, Stetzer M, Line C, et al. Prophylactic Sacral Dressing for pressure ulcer prevention in high-risk patients. Am J Crit Care. 2016;25(3):228-34. https://doi.org/10.4037/ajcc2016979

4. Borghardt AT, Prado TN, Bicudo SDS, Castro DS, Bringuente MEO. Pressure ulcers in critically ill patients: incidence and associated factors. Rev Bras Enferm. 2016;69(3):431-8. https://doi.org/10.1590/0034-7167.2016690307i

5. National Pressure Ulcer Advisory Panel. Resources[Internet]. 2016 [cited 2016 Aug 10]. Available in: http://www.npuap.org/resources/ educational-and-clinical-resources/npuap-pressure-ulcer-stagescategories/

6. Costa AM, Matozinhos ACS, Trigueiro PS, Cunha RCG, Moreira LR. Costs of treatment pressure ulcers in long-term care unit in an institution of Minas Gerais. Rev Enferm [Internet]. 2015 [cited 2016 Apr 15];18(1):58-74. Available from: http://periodicos.pucminas.br/index.php/ enfermagemrevista/article/view/9378

7. Smaniotto PHS, Ferreira MC, Isaac C, Galli R. Systematization of dressings for clinical treatment of wounds. Rev Bras Cir Plást [Internet]. 2012 [cited 2017 May 23];27(4):623-6. Available from: http://www.scielo.br/pdf/rbcp/v27n4/26.pdf

8. Ganong LH. Integrative reviews of nursing research. Rev Nurs Health. 1987;10(1):1-11. https://doi.org/10.1002/nur.4770100103

9. Joanna Briggs Institute (JBI). Reviewer Manual [Internet]. 2014 [cited 2017 May 23]. Available from: http://joannabriggs.org/assets/docs/ sumari/ReviewersManual-2014.pdf 
Products and technologies for treating patients with evidence-based pressure ulcers Figueira TN, Backes MTS, Knihs NS, Maliska ICA, Amante LN, Bellaguarda MLR.

10. Bellingeri A, Falciani F, Traspedini P, Moscatelli A, Russo A, Tino G, et al. Effect of a wound cleansing solution on wound bed preparation and inflammation in chronic wounds: a single-blind RCT. J Wound Care. 2016;25(3):162-6. https://doi.org/10.12968/jowc.2016.25.3.160

11. Fulco I, Erba P, Valeri RC, Vournakis J, Schaefer DJ. Poly-N-acetyl glucosamine nanofibers for negative-pressure wound therapies. Wound Repair Regen. 2015;23(2):197-202. https://doi.org/10.1111/wrr.12273

12. Azimian J, Nayeri ND, Pourkhaleghi E, Ansari M. Transdermal wound oxygen therapy on pressure ulcer healing: a single-blind multi-center randomized controlled trial. Iran Red Crescent Med J. 2015;17(11):e20211. https://doi.org/10.5812/ircmj.20211

13. Farsaei S, Khalili H, Farboud ES, Khazaeipour Z. Sildenafil in the treatment of pressure ulcer: a randomised clinical trial. Int Wound J. 2015;12(1):111-7. https://doi.org/10.1111/iwj.12104

14. Panahi Y, Izadi M, Sayyadi N, Rezaee R, Jonaidi-Jafari N, Beiraghdar F, et al. Comparative trial of Aloe vera/olive oil combination cream versus phenytoin cream in the treatment of chronic wounds. J Wound Care. 2015;24(10):459-60. https://doi.org/10.12968/jowc.2015.24.10.459

15. Ramos-Torrecillas J, García-Martínez O, De Luna-Bertos E, Ocaña-Peinado FM, Ruiz C. Effectiveness of platelet-rich plasma and hyaluronic acid for the treatment and care of pressure ulcers. Biol Res Nurs. 2015;17(2):152-8. https://doi.org/10.1177/1099800414535840

16. Farsaei S, Khalili H, Farboud ES, Karimzadeh I, Beigmohammadi MT. Efficacy of topical atorvastatin for the treatment of pressure ulcers: a randomized clinical trial. Pharmacother. 2014;34(1):19-27. https://doi.org/10.1002/phar.1339

17. Kim JY, Pak CS, Park JH, Jeong JH, Heo CY. Effects of polydeoxyribonucleotide in the treatment of pressure ulcers. J Korean Med Sci. 2014;29(Suppl3):S222-S227. https://doi.org/10.3346/jkms.2014.29.S3.S222

18. Polak A, Franek A, Taradaj J. High-Voltage pulsed current electrical stimulation in wound treatment. Adv Wound Care. 2014;3(2):104-17. https://doi.org/10.1089/wound.2013.0445

19. Bito S, Mizuhara A, Oonishi S, Takeuchi K, Suzuki M, Akiyama K, et al. Randomised controlled trial evaluating the efficacy of wrap therapy for wound healing acceleration in patients with NPUAP stage II and III pressure Ulcer. BMJ Open. 2012;2(1):e000371. https://doi.org/10.1136/ bmjopen-2011-000371

20. Milne $\mathrm{CT}$, Ciccarelli A, Lassy M. A comparison of collagenase to hydrogel dressings in maintenance debridement and wound closure. Wounds [Internet]. 2012 [cited 2017 Jun 15];24(11):317-22. Available from: http://www.woundsresearch.com/files/wounds/WOUNDS_ November2012_Milne.pdf

21. Wild T, Bruckner M, Payrich M, Schwarz C, Eberlein T, Andriessen A. Eradication of methicillin-resistant Staphylococcus aureus in pressure ulcers comparing a polyhexanide-containing cellulose dressing with polyhexanide swabs in a prospective randomized study. Adv Skin Wound Care. 2012;25(1):17-22. https://doi.org/10.1097/01.ASW.0000410686.14363.e

22. Franek A, Kostur R, Polak A, Taradaj J, Szlachta Z, Blaszczak E, et al. Using high-voltage electrical stimulation in the treatment of recalcitrant pressure ulcers: results of a randomized, controlled clinical study. Ostomy Wound Manage [Internet]. 2012 [cited 2016 Nov 21];58(3):30-44. Available from: https://www.ncbi.nlm.nih.gov/pubmed/22391955

23. Chuangsuwanich A, Charnsanti O, Lohsiriwat V, Kangwanpoom C, Thong-In N. The efficacy of silver mesh dressing compared with silver sulfadiazine cream for the treatment of pressure ulcers. J Med Assoc Thai. 2011 [cited 2016 Nov 21];94(5):559-65. Available from: https:// pubmed.ncbi.nlm.nih.gov/21675444/

24. De Laat EH, Van den Boogaard MH, Spauwen PH, van Kuppevelt DH, van Goor H, Schoonhoven L. Faster wound healing with topical negative pressure therapy in difficult-to-heal wounds: a prospective randomized controlled trial. Ann Plast Surg. 2011;67(6):626-31. https:// doi.org/10.1097/SAP.0b013e31820b3ac1

25. Felzani G, Spoletini I, Convento A, Di Lorenzo B, Rossi P, Miceli M, et al. Effect of lysine hyaluronate on the healing of decubitus ulcers in rehabilitation patients. Adv Ther. 2011;28(5):439-45. https://doi.org/10.1007/s12325-011-0016-2

26. Santos SV, Costa R. Prevention of newborn skin lesions: knowledge of the nursing team. Texto Contexto Enferm [Internet]. 2015;24(3):731-9. https://doi.org/10.1590/0104-0707201501123_014

27. Brandão ES, Santana MH, Santos I. A challenge in nursing care: preventing pressure ulcers in the client. Rev Pesqui: Cuid Fundam[Internet]. 2013;5(1):3221-28. https://doi.org/10.9789/2175-5361.2013v5n1p3221

28. Pereira AGS, Santos CT, Menegon DB, Mello B, Azambuja F, Lucena AF. Mapping the nursing care with the NIC for patients in risk for pressure ulcer. Rev Esc Enferm USP. 2014;48(3):454-61. https://doi.org/10.1590/S0080-623420140000300010

29. Baratieri T, Sangaleti CT, Trincaus MR. Nursing academics' knowledge about wounds assessment and treatment. Rev Enferm Atenç Saúde. 2015;4(1):2-15. https://doi.org/10.18554/

30. Gouveia BLA, Albuquerque AM, Oliveira SHS, Silva AP, Oliveira LBP, Costa MML. Wound management: empirical practices under the cultural and religious point of view. Rev Enferm UFPE. 2015;9(2):7046-54. https://doi.org/10.5205/reuol.7505-65182-1-RV.0903201504

31. Lima AFC, Castilho V. Body mobilization for prevention of pressure ulcers: direct labor costs. Rev Bras Enferm. 2015;68(5):647-52. https://doi. org/ 10.1590/0034-7167.2015680523i

32. Lupiáñez-Pérez I, Morilla-Herrera JC, Ginel-Mendoza L, Martín-Santos FJ, Navarro-Moya FJ, Sepúlveda-Guerra RP, et al. Effectiveness of olive oil for the prevention of pressure ulcers caused in immobilized patients within the scope of primary health care: study protocol for a randomized controlled trial. Trials [Internet]. 2013 [cited 2017 Dec 10];23(14):348. Available from: https://trialsjournal.biomedcentral.com/ articles/10.1186/1745-6215-14-348 
33. Donato-Trancoso A, Monte-Alto-Costa A, Romana-Souza B. Olive oil-induced reduction of oxidative damage and inflammation promotes wound healing of pressure ulcers in mice. J Dermatol Sci. 2016;83(1):60-9. https://doi.org/10.1016/j.jdermsci.2016.03.012

34. Pott FS, Meier MJ, Stocco JGD, Crozeta K, Ribas JD. The effectiveness of hydrocolloid dressings versus other dressings in the healing of pressure ulcers in adults and older adults: a systematic review and meta-analysis. Rev Latino-Am Enfermagem. 2014;22(3):511-20. https:// doi.org/10.1590/0104-1169.3480.2445

35. Korelo RIG, Oliveira JJJ, Souza RSA, Hullek RF, Fernandes LC. High frequency generator as treatment in scar pressure ulcers: pilot study. Fisioter Mov. 2013;26(4):715-24. https://doi.org/ISSN 0103-5150

36. Driver VR, Yao M, Kantarci A, Gu G, Park N, Hasturk H. A prospective, randomized clinical study evaluating the effect of transdermal continuous oxygen therapy on biological processes and foot ulcer healing in persons with diabetes mellitus. Ostomy Wound Manage [Internet]. 2013 [cited 2016 Jun 15];59(11):19-26. Available from: https://www.ncbi.nlm.nih.gov/pubmed/24201169

37. Silva AJ, Pereira SM, Rodrigues A, Rocha AP, Varela J, Gomes LM, et al. Economic cost of treating pressure ulcers: a theoretical approach. Rev Esc Enferm USP. 2013;47(4):967-72. https://doi.org/10.1590/S0080-623420130000400028

38. Choi EP, Chin WY, Wan EY, Lam CL. Evaluation of the internal and external responsiveness of the Pressure Ulcer Scale for Healing (PUSH) tool for assessing acute and chronic wounds. J Adv Nurs. 2016;72(5):1134-43. https://doi.org/10.1111/jan.12898

39. Xiao-Qin H, Hong-Lin C. Hydrocolloid vs Gauze dressings in treating pressure ulcers: a meta-analysis of randomized controlled trials. Wounds [Internet]. 2014 [cited 2018 Jul 15];26(9):E60-64. Available from: http://www.woundsresearch.com/article/ hydrocolloid-vs-gauze-dressings-treating-pressure-ulcers-meta-analysis-randomized-controll-0

40. Joyce CW, Regan PJ. An external use of a tissue expander. J Plastic Reconst Aesthetic Surg. 2015;68(8):1154-5. https://doi.org/10.1016/j. bjps.2015.04.001

41. Styrczewska M, Kostyn A, Kulma A, Majkowska-Skrobek G, Augustyniak D, Prescha A, et al. Flax fiber hydrophobic extract inhibits human skin cells inflammation and causes remodeling of extracellular matrix and wound closure activation. BioMed Research Int. 2015;15 pages. https://doi.org/https://doi.org/10.1155/2015/862391

42. Côrtes SMS. Wound treatment: a revision article. Rev Divulg Científ Sena Aires [Internet]. 2013 [cited 2018 May 30];2(1):55-64. Available from: http://revistafacesa.senaaires.com.br/index.php/revisa/article/view/46/45

43. Reddy M, Gill SS, Wu W, Kalkar SR, Rochon PA. Does this patient have an infection of a chronic wound? JAMA. 2012;307(6):605-11. https:// doi.org/10.1001/jama.2012.98

44. Misokami F, Furuta K, Izoqai Z. Necrotizing soft tissue infections developing from pressure ulcers. JTissue Viability. 2014;23(1):1-6. https:// doi.org/10.1016/j.jtv.2013.11.001

45. Moser H, Pereima RR, Pereima MJL. Evolution of silver dressings in the treatment of partial thickness Burns. Rev Bras Queimad [Internet]. 2013 [cited 2016 Jul 13];12(2):60-7. Available from: http://www.rbqueimaduras.com.br/details/147/pt-BR

46. Carneiro CM, Sousa FB, Gama FN. Treatment of wounds: assistance of nursing in the units of primary attention to the health. Rev Enferm Integr [Internet]. 2010 [cited 2017 Aug 20];3(2):494-505. Available from: https://www.unilestemg.br/enfermagemintegrada/artigo/V3_2/03tratamento-de-ferias-assitencia-de-enfermagem.pdf

47. Bavaresco T, Lucena AF. Nursing Intervention Classifications (NIC) validated for patients at risk of pressure ulcers. Rev Latino-Am Enfermagem. 2012;20(6):1109-16. https://doi.org/10.1590/s0104-11692012000600013

48. Rogenski NMB, Kurcgant P. The incidence of pressure ulcers after the implementation of a prevention protocol. Rev Latino-Am Enfermagem. 2012;20(2):07 telas. https://doi.org/10.1590/S0104-11692012000200016 